\title{
NITROGEN FERTILIZATION ASSOCIATED WITH COLD STORAGE AND ITS IMPACTS ON THE MAINTENANCE OF PEACH QUALITY
}

\author{
ADUBAÇÃO NITROGENADA ASSOCIADA AO ARMAZENAMENTO \\ REFRIGERADO E SEUS IMPACTOS NA MANUTENÇÃO DA QUALIDADE DE \\ PESSEGOS
}

\author{
Caroline Farias BARRETO' ${ }^{1}$; Renan NAVROSKI ${ }^{1}$; Letícia Vanni FERREIRA²; \\ Jorge Atílio BENATI ${ }^{1}$; Marcelo Barbosa MALGARIM ${ }^{3}$; Luis Eduardo Correa ANTUNES ${ }^{4}$ \\ 1. Doutorando em Agronomia, Universidade Federal de Pelotas, Pelotas, RS, Brasil; 2. Dra. em Agronomia RS, Brasil; 3. Dr. e \\ Professor, Universidade Federal de Pelotas, Pelotas, RS, Brasil.; 4. Dr. e Pesquisador, Embrapa Clima Temperado, Pelotas, RS, Brasil.
}

\begin{abstract}
Nitrogen, which is considered the most important nutrient for peach trees, may interfere in both quantitative production characteristics and quality of fruits. This study aimed at evaluating the effect of the combination of doses of $\mathrm{N}$ fertilization and different periods of cold storage on physico-chemical and phytochemical characteristics of peaches in post-harvest. The experiment had a randomized complete block design in a $4 \times 3$ factorial scheme, i. e., four doses of fertilization $\left(0,60,120\right.$ and $\left.180 \mathrm{Kg} \mathrm{N} \mathrm{ha}{ }^{-1}\right)$ and three periods of storage (on the harvest day, on both the 15th and the 30th storage days at $1 \pm 1^{\circ} \mathrm{C}$, each followed by a day of simulated commercialization at $20 \pm 1^{\circ} \mathrm{C}$ ). The following aspects were evaluated in fruits yielded by peach trees of the genotype Cascata 1067: fruit color, soluble solid content, titratable acidity, pulp firmness, mass loss, total phenolic compounds and antioxidant activity. Different periods of cold storage and doses of $\mathrm{N}$ fertilization were found to affect epidermis luminosity, pulp firmness and titratable acidity of fruits. Peaches may be stored at low temperatures for $15+1$ days. After that, loss of fruit firmness increases. $\mathrm{N}$ fertilization affects neither the soluble solid content nor the epidermis color of peaches, but both parameters are influenced by storage. Values of phenolic compounds and antioxidant activity decrease when there is $\mathrm{N}$ increment in the soil and when longer storage is carried out. Results suggest that peach composition may be affected by cultural practices, such as $\mathrm{N}$ fertilization, in harvest and after storage.
\end{abstract}

KEYWORDS: Physico-chemical characteristics. Bioactive compounds. Storage. Prunus persica

\section{INTRODUCTION}

Peach is a highly valued fruit worldwide due to its flavor, appearance and economic value in the production chain (MODESTO et al., 2014). The culture of peach trees stretches over 17,605 hectares in Brazil, mainly in both southern and southeastern regions, where Rio Grande do Sul (RS), São Paulo and Santa Catarina states yield about 146, 35 and 18 ton of peaches, respectively (IBGE, 2017). Regarding commercialization, mainly of fruit to be consumed fresh, it is fundamental to yield highquality fruits since, according to Trevisan et al. (2010), attributes, such as size, color, flavor and absence of defects, attract consumers and play a decisive role at the time of purchase. These quality characteristics are closely related to the cultivar genetics, to edafoclimatic conditions and to the use of cultural techniques, such as adequate irrigation, pruning, phytosanitary treatments, thinning and fertilization (GONÇALVES et al., 2014; PEREIRA; RASEIRA, 2014; FERREIRA et al., 2018).

Nitrogen $(\mathrm{N})$ is the most important nutrient for stone fruit trees (ROMBOLÀ et al., 2012); it is the second most exported mineral element through fruits yielded by peach trees (TAGLIAVINI et al., 2000) and the most exported one through leaves and twigs (XILOYANNIS; CELANO; NUZZO, 2006). Therefore, $\mathrm{N}$ fertilization is essential to peach trees, since it may interfere in aspects related to vegetative growth, productivity and fruit quality (DOLINSKI et al., 2005; FALGUERA et al., 2012; FERREIRA et al., 2018; DOLINSKI et al., 2018). $\mathrm{N}$ excess may stimulate vegetative growth of peach trees (DELLA BRUNA; BACK, 2014; FERREIRA et al., 2018), while $\mathrm{N}$ deficiency may affect plant photosynthesis (LEAL et al., 2007).

$\mathrm{N}$ fertilization may also exert influence on qualitative characteristics of fruits, such as size (DELLA BRUNA; BACK, 2014), epidermis color (BARRETO et al., 2017), pulp firmness, soluble solid content (CAMPOS et al., 1996), phenolic compounds, antioxidant activity (FERREIRA et al., 2016; BARRETO et al., 2017; VASHISTH et al., 2017) and carotenoid content (FERREIRA et al., 2016).

Since there are very few data on the effect of $\mathrm{N}$ on physico-chemical characteristics of fruits, 
mainly on their bioactive compounds during storage, this study aimed at evaluating the effect of the combination of doses of $\mathrm{N}$ fertilization and different periods of cold storage on physicochemical and phytochemical characteristics of peaches in post-harvest.

\section{MATERIAL AND METHODS}

In this experiment, fruits were collected at the experimental orchard that belongs to the Embrapa Clima Temperado (latitude $31^{\circ} 40^{\prime} 41.29$ " $\mathrm{S}$; longitude $52^{\circ} 26^{\prime} 22.05^{\prime \prime} \mathrm{W}$; altitude $70 \mathrm{~m}$ ), located in Pelotas, RS, Brazil. Fruits - harvested in the 2017 crop - from peach trees of the genotype Cascata 1067, grafted on the rootstock Capdeboscq, which had been implanted in 2012 in densified cultivation, were used. Spacing between rows was
$5.0 \mathrm{~m}$ while between plants, it was $1.5 \mathrm{~m}$. Plants were conducted in an epsilon system. The genotype Cascata 1067, which originated from crossings between BR 3 and A 333 cultivars, is a selection of the genetic improvement program carried out by the Embrapa Clima Temperado.

Physico-chemical soil analyses which were carried out before the implementation of the experiment showed the following results: organic matter content was $1.4 \%$, phosphorus content was $17.9 \mathrm{mg} \mathrm{dm}^{-3}$ and potassium content was $155 \mathrm{mg}$ $\mathrm{dm}^{-3}$. Data on mean temperature and monthly precipitation (Table 1) were collected in the meteorological station at the Embrapa Clima Temperado, in Pelotas, RS, Brazil. In 2017, 77 cold hours, which were based on temperatures below or equal $7.2^{\circ} \mathrm{C}$ were registered.

Table 1. Mean temperature and precipitation at the Embrapa Clima Temperado, in Pelotas, RS, Brazil, in 2017

\begin{tabular}{lll}
\hline & Mean temperature $\left({ }^{\circ} \mathrm{C}\right)$ & Precipitation $(\mathrm{mm})$ \\
\hline January & 23.5 & 125 \\
February & 24.4 & 234 \\
March & 21.6 & 140 \\
April & 19.0 & 135 \\
May & 16.7 & 221 \\
June & 14.9 & 138 \\
July & 15.3 & 32 \\
August & 15.3 & 232 \\
September & 18.4 & 192 \\
October & 18.4 & 258 \\
November & 19.4 & 40 \\
December & 22.7 & 46 \\
\hline
\end{tabular}

The experiment was conducted as a randomized block design, in a $4 \times 3$ factorial scheme (factor $\mathrm{A}=$ doses of nitrogen; factor $\mathrm{B}=$ storage periods), with four replicates of 20 fruits per unit. Factor A corresponded to doses of $0,60,120$ and $180 \mathrm{Kg} \mathrm{N} \mathrm{ha}{ }^{-1}$, distributed in three applications: $50 \%$ of the dose at full bloom, $30 \%$ after thinning and $20 \%$ after harvest. The $\mathrm{N}$ source, which was urea $(45 \% \mathrm{~N})$, was applied to the surface of the soil. Potassium fertilization was carried out in agreement with recommendations (CQFS-RS/SC, 2016). In the orchard, both fructification pruning and green pruning were carried out in winter and in summer, respectively. Manual fruit thinning aimed at leaving mean distance from 10 to $15 \mathrm{~cm}$ among fruits on peach tree branches. Control of spontaneous plants consisted in using herbicides on the planting area and mowing between rows.

Factor B corresponds to storage periods harvest day (day 0 ) and both the 15 th and the 30 th cold days were followed by a day of simulated commercialization (day $15+1$ and day $30+1$ ). Fruits were stored in a cold chamber (storage days at $1 \pm 1^{\circ} \mathrm{C}$ and at $85-90 \%$ relative air humidity) in the laboratory Lab/Agro, at the Universidade Federal de Pelotas, located in Pelotas, RS, Brazil. In order to simulate commercialization, fruits were removed from the cold chamber and kept in a room at controlled temperature $\left(20 \pm 1^{\circ} \mathrm{C}\right)$.

Peaches were evaluated regarding the following parameters: epidermis color was examined by a Minolta CR-300® colorimeter, with a D65 light source that measured "L" (luminosity), "a*", "b*", and the hue or chromatic tonality represented by "Hue"; fresh mass loss was determined by the difference between fruit masses at harvest time and at storage evaluation; pulp firmness (Newtons) was measured at two opposite points in the equatorial region of peeled fruit by a manual penetrometer (model 53205, TR TURONI- 
Italy) with an $8 \mathrm{~mm}$ tip; total soluble solids ( ${ }^{\circ} \mathrm{Brix}$ ) were measured by an Atago digital refractometer; and total titratable acidity (\% citric acid) was quantified in $10 \mathrm{~mL}$ juice diluted in $90 \mathrm{~mL}$ distilled water, titrated with $0.1 \mathrm{~mol} \mathrm{~L} \mathrm{NaOH}$ solution to $\mathrm{pH}$ 8.1 and measured by a Quimus pHmeter.

The following analyses were performed to determine phytochemicals in peach pulp. Total phenolic compounds (mg Gallic acid equivalent 100 $\mathrm{g}^{-1}$ fresh weight) were determined by the method adapted from Singleton and Rossi Junior (1965), which uses the reaction with the Folin-Ciocalteau reagent. Antioxidant activity (mg equivalent trolox $100 \mathrm{~g}^{-1}$ fresh weigh) was determined by the radical DPPH method, adapted from Brand-Williams, Cuvelier and Berset (1995).

Data were submitted to the analysis of variance (F-Test); means were compared by the Tukey's range test to identify significant differences $(p \leq 0.05)$. Results were submitted to the analysis of variance; when effects were significant, regression equations were adjusted.

\section{RESULTS AND DISCUSSION}

There was interaction among factors under study (doses of $\mathrm{N}$ and periods of storage) in the case of the following variables: epidermis luminosity, pulp firmness and titratable acidity of peaches (Table 2).

Regarding peach epidermis, plants with no $\mathrm{N}$ fertilization provided higher luminosity values on the harvest day, i. e., epidermis luminosity was lighter. This result may be related to plant vigor since, with no $\mathrm{N}$ fertilization, peach trees developed less in the aerial part (DELLA BRUNA; BACK, 2014; FERREIRA et al., 2018), a fact that interfered in the solar luminosity and radiation of the crown and, consequently, led to fruits with more luminosity. However, on the other storage days $(15+1$ and $30+1)$, there were no differences among doses of $\mathrm{N}$ in the case of the variable luminosity.

Table 2. Luminosity of epidermis, firmness of pulp (Newtons) and titratable acidity ( $\mathrm{g}$ of citric acid per $100 \mathrm{~mL}$ juice) of peach fruits 'Cascata 1067' submitted to different doses of nitrogen and storage periods

\begin{tabular}{|c|c|c|c|c|c|c|}
\hline \multicolumn{7}{|c|}{ Storage periods } \\
\hline \multirow{2}{*}{\multicolumn{7}{|c|}{$\begin{array}{l}\text { Doses of } \mathbf{N}\left(\mathbf{k g ~ h a}^{-1}\right) \\
\text { Luminosity of epidermis }\end{array}$}} \\
\hline & & & & & & \\
\hline 0 & 64.00 & $\mathrm{aA}$ & 56.16 & $\mathrm{aB}$ & 53.17 & $\mathrm{aB}$ \\
\hline 60 & 59.30 & $\mathrm{bA}$ & 55.64 & $\mathrm{aAB}$ & 54.13 & $\mathrm{aB}$ \\
\hline 120 & 61.25 & $\mathrm{abA}$ & 56.52 & $\mathrm{aB}$ & 56.04 & $\mathrm{aB}$ \\
\hline 180 & 62.83 & $\mathrm{abA}$ & 53.83 & $\mathrm{aB}$ & 55.45 & $\mathrm{aB}$ \\
\hline CV (\%) & 3.82 & & & & & \\
\hline \multicolumn{7}{|l|}{ Firmness of pulp } \\
\hline 0 & 27.53 & $\mathrm{aA}$ & 11.78 & $\mathrm{aB}$ & 6.13 & $\mathrm{aC}$ \\
\hline 60 & 21.63 & $\mathrm{bA}$ & 9.70 & $\mathrm{aB}$ & 5.65 & $\mathrm{aC}$ \\
\hline 120 & 20.21 & $\mathrm{bA}$ & 12.40 & $\mathrm{aB}$ & 5.97 & $\mathrm{aC}$ \\
\hline 180 & 26.51 & $\mathrm{aA}$ & 9.35 & $\mathrm{aB}$ & 5.78 & $\mathrm{aC}$ \\
\hline CV (\%) & & & & & & \\
\hline \multicolumn{7}{|l|}{ Titratable acidity } \\
\hline 0 & 0.55 & $\mathrm{aA}$ & 0.34 & $\mathrm{aB}$ & 0.24 & $\mathrm{aC}$ \\
\hline 60 & 0.49 & $\mathrm{bA}$ & 0.34 & $\mathrm{aB}$ & 0.24 & $\mathrm{aC}$ \\
\hline 120 & 0.43 & $\mathrm{cA}$ & 0.32 & $\mathrm{aB}$ & 0.22 & $\mathrm{aC}$ \\
\hline 180 & 0.46 & bcA & 0.28 & $\mathrm{bB}$ & 0.24 & $\mathrm{aC}$ \\
\hline
\end{tabular}

CV (\%) 6.02

Means followed by same letters, lowercase in the columns and uppercase in the lines, do not differ by the Tukey's test, at $5 \%$ probability $(\mathrm{p} \leq 0.05) . \mathrm{CV}(\%)=$ Coefficient of variation.

Epidermis luminosity decreased during the cold storage of peaches, i. e., fruits darkened (Table 2).

Luminosity of fruits may decrease due to their metabolism and storage conditions. 'Aurora-1' peaches also decreased their luminosity values after cold storage when they were harvested ripe (JUNIOR; DURIGAN; MATTIUZ, 2010). Similar results were found when 'Cascata 1513' peaches an advanced selection of the genetic improvement program carried out by the Embrapa Clima Temperado - were submitted to cold storage and 
also exhibited decrease in luminosity $15+1$ days after storage (BARRETO et al., 2017).

Pulp firmness was higher in fruits yielded by plants which had not been fertilized with $\mathrm{N}$ and when they had been fertilized with $180 \mathrm{~kg} \mathrm{ha}^{-1}$ on harvest day (Table 2). However, on the other storage days $(15+1$ and $30+1)$, there were no differences among doses of $\mathrm{N}$ in the case of this variable. Barreto et al. (2017) found opposite results, i. e., pulp and rind firmness did not show any difference when distinct doses of $\mathrm{N}$ were applied, but values of these variables decreased after cold storage followed by simulated commercialization. Therefore, fruit firmness depends on other factors, such as the cultivar, weather conditions, plant management (irrigation), fruit orientation in the plant and exposure to sunlight (ALCOBENDAS et al., 2013), besides cold storage (ANDRADE et al., 2015).

Pulp firmness decreased after cold storage followed by simulated commercialization, regardless of the dose of $\mathrm{N}$ (Table 2). These data agree with Barreto et al. (2017), who studied peaches of the genotype Cascata 1513 and also observed decrease in firmness after cold storage followed by simulated commercialization. Loss of fruit firmness is expected as time goes by, due to both advance in fruit senescence and solubilization of cell wall components (PEGORARO et al., 2015).

On harvest day, titratable acidity of peaches was higher when plants had not been fertilized with $\mathrm{N}$ (Table 1). However, $\mathrm{N}$ fertilization did not affect fruit acidity after cold storage followed by simulated commercialization. Ferreira et al. (2016) analyzed three genotypes of peach trees submitted to different doses of $\mathrm{N}$ and found contradictory results in two crops under evaluation. In the first crop, $\mathrm{N}$ affected acidity, but, in the next one, there was no significant difference. It shows that this variable may depend on other factors, such as weather conditions, which vary every cultivation year.

After storage, there was decrease in peach acidity, regardless of doses of $\mathrm{N}$ (Table 2). Decrease in acidity is due to the fact that organic acid contents diminish as fruits ripen, as the result of either the respiration process or conversion to sugars (CHITARRA; CHITARRA, 2005).

In the treatment with no $\mathrm{N}$ application, there was low loss of fruit mass (Table 3); it may have happened because fruits with no $\mathrm{N}$ fertilization had low fruit mass. On storage days, mass loss was found to increase as time went by. The highest loss took place after $30+1$ days (Table 2). Peaches may be stored at low temperatures up to $15+1$ days. After this period, mass loss is above $10 \%$; there is pulp softening and turgor loss of tissues (Table 3), which affect fruit quality and commercialization (CRISOSTO et al., 2004). These results agree with Andrade et al. (2015), who found 33\% mass loss in 'Maciel' peaches after a 30-day cold storage period followed by a 2-day simulated commercialization period. Water loss in fruits during storage results mainly from transpiration (MAGUIRE; BANKS, 2000) and is related to the vapor pressure deficit between them and the environment (PINTO et al., 2012).

Table 3. Loss of mass (\%), color of the epidermis $\left({ }^{\circ} \mathrm{Hue}\right)$ and soluble solids ( ${ }^{\circ}$ Brix) of peach fruits 'Cascata $1067^{\prime}$ 'submitted to different doses of nitrogen and storage periods

\begin{tabular}{lllllll}
\hline Doses of N $\left(\mathbf{k g ~ h a}^{-\mathbf{1}}\right)$ & \multicolumn{2}{l}{ Loss of mass } & \multicolumn{2}{l}{ Color the epidermis } & \multicolumn{2}{l}{ Soluble solids } \\
\hline 0 & 9.49 & $\mathrm{~b}$ & 57.72 & $\mathrm{~ns}$ & 14.05 & $\mathrm{~ns}$ \\
60 & 10.66 & $\mathrm{ab}$ & 55.66 & & 15.11 & \\
120 & 10.41 & $\mathrm{ab}$ & 61.98 & & 14.50 & \\
180 & 12.44 & $\mathrm{a}$ & 60.84 & & & \\
\hline Storage periods & & & & $\mathrm{a}$ & 13.99 & \\
\hline Day 0 & 0.00 & $\mathrm{c}$ & 67.30 & $\mathrm{~b}$ & 14.39 & $\mathrm{c}$ \\
Day 15+1 & 8.91 & $\mathrm{~b}$ & 55.62 & $\mathrm{~b}$ & 16.71 & $\mathrm{a}$ \\
Day 30+1 & 23.34 & $\mathrm{a}$ & 54.23 & & 4.27 & \\
\hline CV $(\%)$ & 18.16 & & 10.13 &
\end{tabular}

Means followed by the same lowercase letter do not differ significantly from each other ( $\mathrm{p} \leq 0.05)$, calculated by the Tukey's test. CV $(\%)=$ Coefficient of variation. $n s=$ not significant.

$\mathrm{N}$ fertilization did not affect the epidermis color of peaches (Table 3). Data agree with the ones found by Falguera et al. (2012) and Ferreira et al. (2016), who did not observe differences in peach color as the result of $\mathrm{N}$ fertilization, either. Dolinski et al. (2018) observed that peach color was not altered by $\mathrm{N}$ fertilization in the first two crops; changes only happened in the third crop, when high chromaticity was found at $214 \mathrm{Kg} \mathrm{N} \mathrm{ha}{ }^{-1}$. Alcobendas et al. (2013) state that fruit color is influenced by other factors, such as interaction between irrigation and exposure to sunlight. 
However, epidermis color decreased after $15+1$ and $30+1$ days of storage. ${ }^{\circ}$ Hue values decreased on those days under evaluation and fruits became reddish cream (Table 2). This result is due to the ripening metabolism of fruits, whose ${ }^{\circ} \mathrm{Hue}$ angle decreases during ripening (INFANTE; FARCUH; MENESES, 2008), i. e., chlorophylls continue the degradation process and pigments, such as anthocyanins and carotenoids, become more visible.

$\mathrm{N}$ fertilization did not affect soluble solid contents in peaches (Table 3). Similar results were found by Dolinski et al. (2005), who, in three crops, did not find any effect of $\mathrm{N}$ fertilization on soluble solid contents when peaches were harvested, and by Vashisth et al. (2017), who observed that soluble solid contents in 'Tropic Beauty' peaches were not affected by $\mathrm{N}$ fertilization. This variable has been associated with the location of fruits in the plant, light penetration into the crown, type of twigs, thinning (PICOLOTTO et al., 2009), water absorption by plants as a response to different amounts of rainfall - which can cause sugar dilution in fruits (BRUNETTO et al., 2007) - and interaction between irrigation and exposure to sunlight (ALCOBENDAS et al., 2013).

However, soluble solid contents in peaches increased between harvest and $15+1$ and $30+1$ storage days (Table 3), a fact that confirmed the most advanced stage of fruit ripening, since there is increase in sugar concentration as fruits ripen (JIE et al., 2013). It also occurs due to high percentages of mass loss during storage, since they determine high sugar concentration and, thus, increase in soluble solid contents.

Phenolic compounds decreased as N fertilization increased in the soil; they decreased in about $31 \%$ when $\mathrm{N}$ was between 0 and $180 \mathrm{~kg} \mathrm{ha}^{-1}$ (Figure 1). The same fact was observed in fruits yielded by both 'Tropic Beauty' and 'UFSharp' peach tree cultivars, when doses of $\mathrm{N}$ were 0,45 , 90, 179, and $269 \mathrm{~kg} \mathrm{ha}^{-1}$ per year (VASHISTH et al., 2017). According to Strissel et al. (2005), decrease in phenolic compound contents, when there is $\mathrm{N}$ increment in the soil, is mainly related to reduction in flavonoid synthesis, as a response to decrease in the enzyme phenylalanine ammonialyase (PAL) contents. Alterations in this enzyme may influence fruit secondary metabolism, since PAL is the key enzyme in phenol metabolism. Environmental stress, such as nitrogen deficiency, may increase the amount of PAL and result in higher synthesis of phenolic compounds (TAIZ et al., 2017).

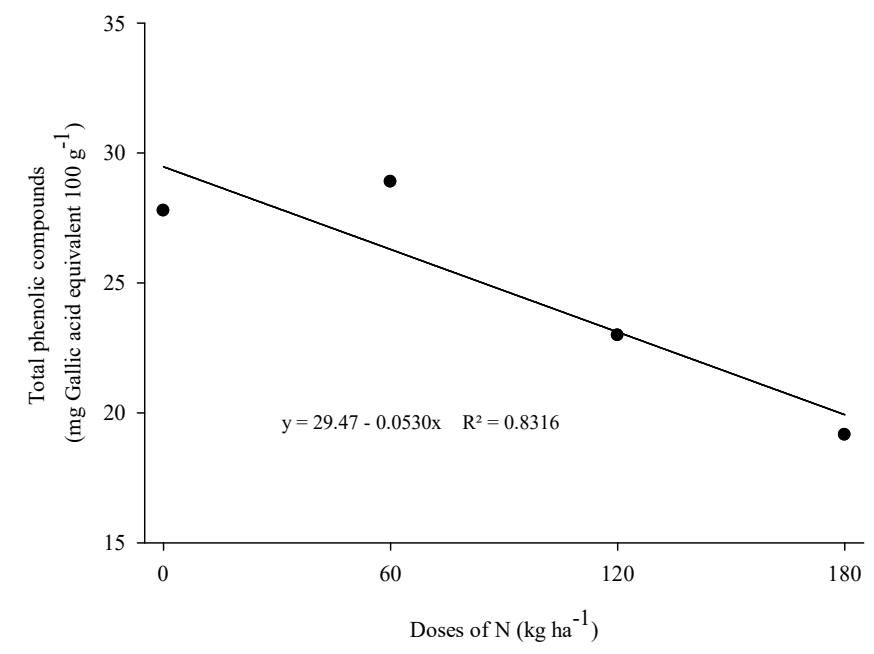

Figure 1. Total phenolic compounds of peach fruits 'Cascata 1067' submitted with different doses of nitrogen fertilization.

Antioxidant activity of peaches also decreased their contents when the highest doses of $\mathrm{N}$ were in the soil (120 and $\left.160 \mathrm{~kg} \mathrm{ha}^{-1}\right)$ (Figure 2). Similar results were found by Vashisth et al. (2017), who observed decrease in the antioxidant capacity of two peach cultivars when doses of $\mathrm{N}$ increased. They also reported a significant and positive relation between the antioxidant activity and the phenolic content in both cultivars. 


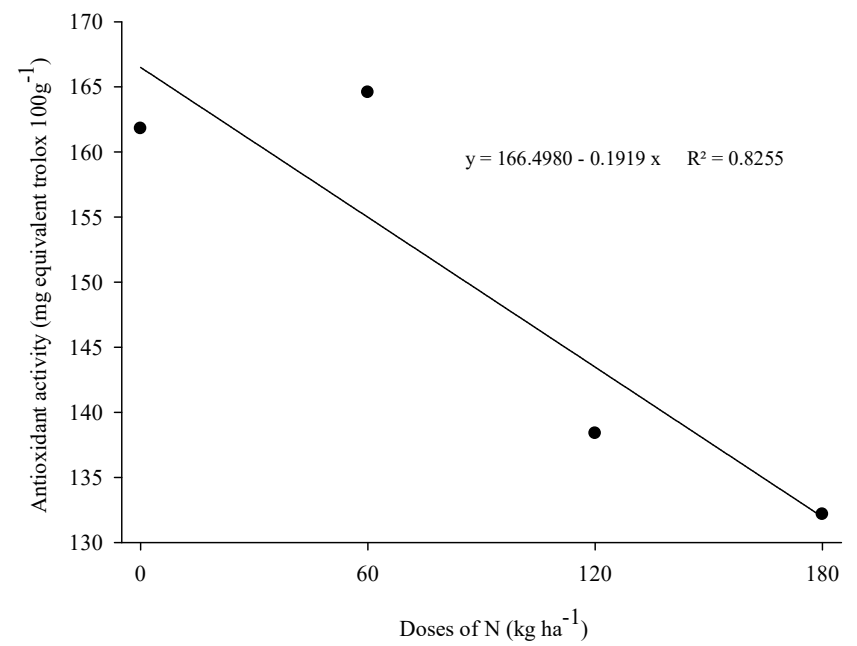

Figure 2. Antioxidant activity of 'Cascata 1067' peach fruits submitted to different doses of nitrogen fertilization.

In cold storage, peaches submitted to $\mathrm{N}$ fertilization decreased their total phenolic compound contents and antioxidant activity (Table 4). Santos et al. (2013) also observed decrease in the antioxidant capacity in 'Aurora', 'Biuti' and 'Douradão' peaches after a 5-day storage period at room temperature, by comparison with the one on harvest day. Barreto et al. (2017) found decrease in bioactive compounds in 'Cascata 1513' peaches after a 15-day cold storage period followed by a day of simulated commercialization. This decrease may be attributed to chemical and enzymatic alterations which occur during fruit storage.

Table 4. Total phenolic compounds and antioxidant activity of 'Cascata 1067' peach fruits in different storage periods.

\begin{tabular}{lllll}
\hline Storage periods. & \multicolumn{2}{l}{ Total phenolic compounds ${ }^{1}$} & \multicolumn{2}{l}{ Antioxidant activity $^{2}$} \\
\hline Day 0 & 33.69 & $\mathrm{a}$ & 180.80 & $\mathrm{a}$ \\
Day15+1 & 22.54 & $\mathrm{~b}$ & 148.19 & $\mathrm{~b}$ \\
Day 30+1 & 17.87 & $\mathrm{~b}$ & 118.70 & $\mathrm{c}$ \\
\hline CV $(\%)$ & 29.73 & & 20.65 & \\
\hline
\end{tabular}

$\mathrm{CV}(\%)=$ Coefficient of variation. ${ }^{1} \mathrm{mg}$ Gallic acid equivalent $100 \mathrm{~g}^{-1}$ fresh weight. ${ }^{2} \mathrm{mg}$ equivalent trolox $100 \mathrm{~g}^{-1}$ fresh weight. Means followed by the same lowercase letter do not differ significantly from each other $(p \leq 0.05)$, calculated by the Tukey's test.

\section{CONCLUSIONS}

Combinations of different cold storage periods and distinct doses of $\mathrm{N}$ fertilization affect epidermis luminosity, pulp firmness and titratable acidity.

Peaches may be stored at low temperatures for $15+1$ days.
$\mathrm{N}$ fertilization affects neither soluble solid contents nor epidermis color of peaches, but these parameters are influenced after storage.

Phenolic compounds and antioxidant activity decrease when there is increment in $\mathrm{N}$ fertilization in the soil.

RESUMO: O nitrogênio é o nutriente considerado de maior importância para o pessegueiro, podendo interferir nas características quantitativas da produção, bem como na qualidade dos frutos. O objetivo do trabalho foi avaliar o efeito da combinação de doses de adubação nitrogenada e de diferentes períodos de armazenamento refrigerado nas características físico-químicas e fitoquímicas de pêssegos na pós-colheita. $\mathrm{O}$ delineamento experimental foi o de blocos casualizados em esquema fatorial $4 \times 2$, quatro doses de adubação $(0$, 60,120 e $180 \mathrm{Kg} \mathrm{N} \mathrm{ha}^{-1}$ ) e três períodos de armazenamento (dia da colheita, aos 15 e 30 dias armazenamento refrigerado a $1 \pm 1^{\circ} \mathrm{C}$, seguido de um dia de simulação de comercialização a $20 \pm 1^{\circ} \mathrm{C}$ ). Avaliou-se, nos frutos de pessegueiro do genótipo Cascata 1067, a coloração dos frutos, o teor de sólidos solúveis, acidez titulável, 
firmeza da polpa, perda de massa, compostos fenólicos totais e a atividade antioxidante. Verificou-se que diferentes períodos de armazenamento refrigerado e doses de adubação nitrogenada afetam a luminosidade da epiderme, a firmeza de polpa e a acidez titulável dos frutos. Os pêssegos podem ser armazenados em baixa temperatura até $15+1$ dias, após esse período, a perda de firmeza nos frutos é elevada. A adubação nitrogenada não altera o teor de sólidos solúveis e a coloração da epiderme dos pêssegos, mas esses parâmetros são influenciados durante o armazenamento. Os compostos fenólicos e atividade antioxidante decrescem com o incremento de nitrogênio no solo, bem como durante o avanço dos dias de armazenamento. Os resultados sugerem que a composição dos pêssegos pode ser afetada com práticas culturais como a adubação de nitrogênio na colheita e após o armazenamento.

Palavras-Chave: Físico-químicas. Compostos bioativo. Armazenamento. Prunus persica.

\section{REFERENCES}

ALCOBENDAS, R.; MIRÁS-AVALOS, J. M.; ALARCÓN, J. J.; NICOLÀS, E. Effects of irrigation and fruit position on size, colour, firmness and sugar contents of fruits in a mid-late maturing peach cultivar. Scientia Horticulturae, v. 164, p. 340-347, 2013. https://doi.org/ 10.1016/j.scienta.2013.09.048

ANDRADE, S. DE B.; PADILHA GALARÇA, S., GAUTÉRIO, G. R., BARBOSA MALGARIM, M.; FACHINELLO, J. C. Qualidade de pêssegos das cultivares Chimarrita e Maciel sob armazenamento refrigerado em diferentes estádios de maturação de colheita. Revista Iberoamericana de Tecnología Postcosecha, v.16, n.1, 93-100, 2015.

BARRETO, C. F.; FERREIRA, L. V.; NAVROSKI, R.; FRASSON, S. F.; CANTILLANO, R. F. F.; VIZZOTTO, M.; ANTUNES, L. E. C. Adubação nitrogenada em pessegueiros (Prunus persica (L) Batsch): influência sobre a qualidade pós-colheita. Revista Iberoamericana de Tecnología, v. 18, n. 2, p.93-99, 2017.

BRAND-WILLIANS, W.; CUVELIER, M. E.; BERSET, C. Use of a free radical method to evaluate antioxidant activity. Food Science and Technology, v.28, n.1, p.25-30, 1995. https://doi.org/10.1016/S00236438(95)80008-5

BRUNETTO, G., DE MELO, G. W., KAMINSKI, J.; CERETTA, C. A. Adubação nitrogenada em ciclos consecutivos e seu impacto na produção e na qualidade do pêssego. Pesquisa Agropecuária Brasileira, v.42, n.12, p.1721-1725, 2007. http://dx.doi.org/10.1590/S0100-204X2007001200008

CAMPOS, A. D.; FREIRE, C. J. S.; NAKASU, B. H.; FORTESW, J. F. Qualidade dos frutos e crescimento dos ramos de pessegueiro em função do nitrogênio e potássio foliar. In: XIV Congresso Brasileiro de Fruticultura, 1996, Curitiba. Anais... Curitiba, PR. SBF, 1996. p.379.

CHITARRA M. I. F.; CHITARRA, A. B. Pós-colheita de frutas e hortaliças: fisiologia e manuseio. 2.ed. Lavras, FAEPE, 783p. 2005.

CQFS-RS/SC - COMISSÃO DE QUÍMICA E FERTILIDADE DO SOLO. Manual de adubação e calagem para os estados do Rio Grande do Sul e Santa Catarina. Núcleo Regional Sul da Sociedade Brasileira de Ciência do Solo, 2016.

CRISOSTO, C. H.; GARNER, D.; ANDRIS, H. L.; DAY, K. R. Controlled delayed cooling extends peach market life. Hort Technology, v.14, n.1, p.99-104, 2004. http://dx.doi.org/10.21273/HORTTECH.14.1.0099

DELLA BRUNA, E. D.; BACK, A. J. Adubação nitrogenada em pessegueiros 'Aurora' e 'Chimarrita'. Revista Tecnologia e Ambiente, v. 20, p. 71-80, 2014. https://doi.org/10.18616/ta.v20i0.1561 
DOLINSKI, M. A.; SERRAT, B. M.; MOTTA, A. C. V.; CUQUEL, F. L.; SOUZA, S. R.; MAY-DEMIO, L. L.; MONTEIRO, L. B. Produção, teor foliar e qualidade de frutos do pessegueiro "Chimarrita" em função da adubação nitrogenada, na região da Lapa - PR. Revista Brasileira de Fruticultura, v.27, n.2, p. 295-299, 2005. http://dx.doi.org/10.1590/S0100-29452005000200027

DOLINSKI, M. A.; DANGELO, J. W. de O.; CUQUEL, F. L.; MOTTA, A. C. V.; MIO, L. L. M. Quality peach produced in fertilizer doses of nitrogen and green pruning. Bragantia, v. 77, n. 1, p. 134-140, 2018. http://dx.doi.org/10.1590/1678-4499.2016307.

FALGUERA, V.; LORDAN, J.; GATIUS, F.; PASCUAL, M., VILLAR, J. M.; IBARZ, A.; RUFAT, J. Influence o nitrogen fertilization on polyphenol oxidase activity in peach fruits. Scientia Horticulturae, v. 142, p. 155-157, 2012. http://dx.doi.org/10.1016/j.scienta.2012.05.014

FERREIRA, L. V.; PICOLOTTO, L.; PEREIRA, I. S.; SCHMITZ, J. D.; ANTUNES, L. E. C. Nitrogen fertilization in consecutive cycles and its impact on high-density peach crops. Pesquisa Agropecuária Brasileira, Brasília, v.53, n.2, p.172-181, 2018. http://dx.doi.org/10.1590/s0100-204x2018000200005

FERREIRA, L. V.; ANTUNES, A. P.; PICOLOTTO, L.; CANTILLANO, R. F. C. Qualidade de pêssegos submetidos à adubação nitrogenada. Revista Iberoamericana de Tecnología Postcosecha, v. 17, n.2, p. 231240, 2016.

INSTITUTO BRASILEIRO DE GEOGRAFIA E ESTATÍSTICA - IBGE. Produção agrícola municipal. 2017. Disponível em: $<$ http://www.sidra.ibge.gov.br/bda/Tabela/listabl.asp? $\mathrm{z}=$ teo $=11 \mathrm{ei}=\mathrm{Pec}=1613>$. Acesso em: 30 set. 2019.

GONÇALVES, M. A.; PICOLOTTO, L.; QUINTANILHA, F. A.; COCCO, C.; ANTUNES, L. E. C. Qualidade de fruto e produtividade de pessegueiros submetidos a diferentes épocas de poda. Ciência Rural, v.44, n.8, p.1334-1340, 2014. http://dx.doi.org/10.1590/0103-8478cr20120617

INFANTE, R.; FARCUH, M.; MENESES, C. Monitoring the sensorial quality and aroma through an electronic nose in peaches during cold storage. Journal of the Science of Food and Agriculture, v.88, p.2073-2078, 2008. https://doi.org/10.1002/jsfa.3316

JIE, D.; XIE, L.; FU, X.; RAO, X.; YING, Y. Variable selection for partial least squares analysis of soluble solids content in watermelon using near-infrared diffuse transmission technique. Journal of Food Engineering, v.118, n.4, p.387-392, 2013. https://doi.org/10.1016/j.jfoodeng.2013.04.027

JUNIOR, L. C. C.; DURIGAN, M. F. B.; MATTIUZ, B. Conservação de pêssegos 'Aurora-1' armazenados sob refrigeração. Revista Brasileira de Fruticultura, v. 32, n. 2, p. 386-396, 2010.

http://dx.doi.org/10.1590/S0100-29452010005000041.

LEAL, R. M.; NATALE, W.; PRADO, R. de M.; ZACCARO, R. P. Adubação nitrogenada na implantação e na formação de pomares de caramboleira. Pesquisa Agropecuária Brasileira, v.42, n.8, p.1111-1119, 2007. http://dx.doi.org/10.1590/S0100-204X2007000800007.

MAGUIRE, K. M.; BANKS, N. H. Harvest date, cultivar, orchard and tree effects on water vapor permanence in apples. Journal of the American Society of Horticultural Science, v.125, n.1, p.100-104, 2000. https://doi.org/10.21273/JASHS.125.1.100

MODESTO, J. H.; VEDOATO, B. T. F.; LEONEL, S.; TECHIO, M. A. Crescimento vegetativo, fenologia, produção e sazonalidade dos frutos de pessegueiros e nectarineira. Revista Magistra, v. 26, n.3, p.425-430, 2014. 
PEGORARO, C.; TADIELlO, A.; GIRARDI, C. L.; CHAVES, F. C.; QUECINI, V.; OLIVEIRA, A. C. DE; TRAINOTTI, L.; ROMBALDI, C. V. Transcriptional regulatory networks controlling woolliness in peach in response to preharvest gibberellin application and cold storage. BMC Plant Biology, v.279, p.1-14, 2015. https://doi.org/10.1186/s12870-015-0659-2

PEREIRA, J. F. M.; RASEIRA, A. Raleio. In: RASEIRA, M. C. B; PEREIRA, J. F. M.; CARVALHO, F. L. C. Pessegueiro. Brasília, DF: Embrapa, 2014. p. 309-327.

PICOLOTTO, L.; MANICA-BERTO, R.; PAZIN, D.; PASA, M. S.; SCHIMITZ, J. D.; PREZOTTO, M. E.; BETEMPS, B.; BIANCHI, V. J.; FACHINELLO, J. C. Características vegetativas, fenológicas e produtivas do pessegueiro cultivar Chimarrita enxertado em diferentes porta-enxertos. Pesquisa Agropecuária Brasileira, v. 44, n.6, p. 583-589, 2009. http://dx.doi.org/10.1590/S0100-204X2009000600006

PINTO, J. A. V.; BRACKMANN, A.; SCHORR, M. R. W.; VENTURIN, T. L.; THEWES, F. R. Indução de perda de massa na qualidade pós-colheita de pêssegos 'Eragil' em armazenamento refrigerado. Ciência Rural, n.42, n.6, p.962-968, 2012. http://dx.doi.org/10.1590/S0103-84782012000600002

ROMBOLÀ, A. D.; SORRENTI, G.; MARODIN G. A. B.; DE PIERI, A. Z.; BARCA, E. Nutrição e manejo do solo em fruteiras de caroço em regiões de clima temperado. Semina: Ciências Agrárias, v. 33, n. 2, 2012. http://dx.doi.org/10.5433/1679-0359.2012v33n2p639

SANTOS, C. M. DOS; ABREU, C. M. P. DE; FREIRE, J. M.; CORREA, A. D. Atividade antioxidante de frutos de quatro cultivares de pessegueiro. Revista Brasileira de Fruticultura, v.35, n.2, p.339-344, 2013. http://dx.doi.org/10.1590/S0100-29452013000200002

SINGLETON, V. L.; ROSSI JUNIOR, J. A. Colorimetry of total phenolics with phosphomolybdicphosphotungstic acid reagents. American Journal of Enology and Viticulture, v.16, n.3, p.144-158, 1965.

STRISSEL, T.; HALBWIRTH, H.; HOYER, U.; ZISTLER, C.; STICH, K.; TREUTTER. D. Growthpromoting nitrogen nutrition affects flavonoid biosynthesis in young apple (Malus domestica Borkh.) leaves. Plant Biology, v.7, n.6, p. 677-685. 2005. http://dx.doi.org/10.1055/s-2005-872989

TAIZ, L.; ZEIGER, E.; MOLLER, I. M.; MURPHY, A. Fisiologia e desenvolvimento vegetal. 6. ed. Porto Alegre: Artmed, 2017. 858 p.

TAGLIAVINI, M.; ZAVALLONI, C.; ROMBOLA, A. D.; QUARTIERI, M.; MALAGUTI, D.; MAZZANTI, F.; MILLARD, P.; MARANGONI, B. Mineral nutrient partitioning to fruits of deciduous trees. Acta Horticulturae, n.512, p.131-140, 2000. http://dx.doi.org/10.17660/ActaHortic.2000.512.13

TREVISAN, R.; PIANA, C. F. DE B.; TREPTOW, R. DE O.; GONÇALVES, E. D.; ANTUNES, L. E. C. Perfil e preferências do consumidor de pêssego (Prunus persica) em diferentes regiões produtoras no Rio Grande do Sul. Revista Brasileira de Fruticultura, v.32, n.1, p. 90-100, 2010. http://dx.doi.org/10.1590/S0100-29452010005000011.

VASHISTH, T.; OLMSTEAD, M. A.; OLMSTEAD, J.; COLQUHOUN, T. A. Effects of Nitrogen Fertilization on Subtropical Peach Fruit Quality: Organic Acids, Phytochemical Content, and Total Antioxidant Capacity. Journal of the American Society for Horticultural Science, v. 142, n. 5, p. 393-404, 2017. https://doi.org/10.21273/JASHS04011-16

XILOYANNIS, C.; CELANO, G.; NUZZO, V. Domanda annuale di elementi minerali in specie arboree da frutto in ambiente mediterraneo. Italus Hortus, v. 13, n. 3, p. 30-34, 2006. 